\title{
Detroit
}

\section{A desktop travelogue for the 9th National Conference}

\author{
by William P. Kane
}

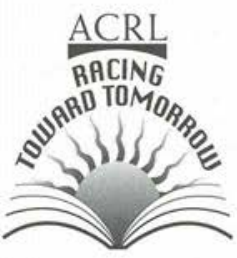

You can't help yourself-whenever you remember that ACRL's upcoming National Conference is going to be in Detroit, you start thinking, "Honolulu, why not Honolulu?" or "Paris, what's wrong with Paris?" Come to think of it, though, it's been a while since you've been to Detroit, and besides, didn't you see the January 1998 CERL News article describing Motown as a hip, hoppin', happenin' place? In addition, you recall more than one recent piece in the national media concerning Detroit's revitalization, and the Red Wings do seem to keep winning those Stanley Cups, so you have to figure that the place is riding pretty high these days.

But still, it's always a good idea to try and get a closer look at a town before actually showing up, suitcase in hand, heading for the convention center. What you might do, you figure, is get an insider's perspective, see what the locals see, get a sneak peek at Detroit's local (albeit gritty) charm.

Like any tourist worth a right-click, you can find the standard weather forecasts and attractions for cities all over the world, from Akron to Zanzibar, in a hurry. You work in a library, have reasonably easy access to the Web, and you're in the mood for some sleuthing, maybe in the guise of professional development. You want to take your time on your virtual travelogue, looking for places that are a bit off-beat, but maybe likewise indicative of the city's soul. So, you fire up your browser, load up the inkjet, crack your knuckles, and have at it.

\section{www.visitdetroit.com}

Standard but useful information to be had here, and not a bad starting point, particularly if you're interested in some quick and quirky facts and figures. For example, you never knew that Detroit has the largest annual fireworks display in the world, or that it's the only U.S. city that's actually north of Canada. However, when you learn that Detroit is the potato chip capital of the world, and that Detroit has more registered bowlers than anywhere else, you figure that may be more than you need to know.

You order some free visitors' guides and move on.

\section{www.dia.org}

Now you're getting somewhere. You'd heard that Detroit has the fifth largest fine arts museum in the United States, and their Web site includes lots of good stuff about upcoming exhibits, permanent collections, and such, but also, and most interestingly, a waycool database of some 1,000 plus digital images of artworks from the collections that you can search, browse, view, and obtain. You knew that museums would start acting like libraries some day. Meanwhile, you're happy to realize that the museum's right up the street from the convention center, because you'd love to see that massive Diego Rivera fresco "Detroit Industry" firsthand, as it's evocative of a place with a pulse.

\section{pewabic.com}

More artsy-craftsy stuff here, further dispelling the notion of Detroit as purely shot-and-

\section{About the author}




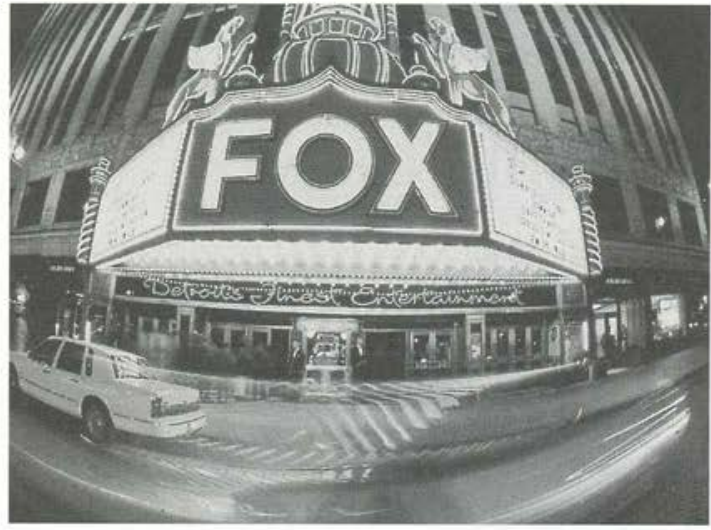

Built in 1928 in the tradition of great movie palaces, this magnificent theater was beautifully restored in 1988 and offers the finest in entertainment from concerts and musicals to magicians and ice shows.

beer blue collar. Pewabic pottery, founded during the Arts and Crafts Movement, is rooted in tradition and elegance. You're quite happy to see that there are public installations throughout the city, and, if you could afford it, you'd plaster the tiles throughout your house. Maybe a small tile as a souvenir is in order.

\section{www.heidelberg.org}

Speaking of art, you can hardly even believe the Heidelberg Project. Artist Tyree Guyton has spent the past 12 years collecting and displaying found objects diartes (some might say "garbage") onto a city street's landscape. House after some otherwise maybe abandoned house on a block of Heidelberg Street is festooned with thousands, maybe millions of big and bright polka dots, punctuated by oddball and somehow sad assortments of life's remnants-baby dolls and old purses and board games and shopping carts and lawn mowers-all covered by those big, bright polka dots. The street is lined with painted, polka dotted shoes and old polka dotted vacuum cleaners. A tall polka dotted tree has old polka dotted telephones nailed all the way up its polka dotted trunk, with polka dotted suitcases sprouting from polka dotted branches like polka dotted leaves. Polka dotted mannequins sit on polka dotted porches smiling out at polka dotted car hoods; polka dotted hubcaps adorn the polka dotted sidewalks lining the polka dotted lawns.
You get the feeling the artist has a thing for polka dots. Go figure. Even if you don't, you can tell it's an eye-popping, jawopening, get-out-of-your-carand-stare, one-of-a-kind city block, and probably worth the quick side trip (following the downloadable maps) when you're in town. You hope that it's still there come April, as you've read that the City Council (no doubt prompted by some polka dot-weary neighbors) is negotiating with the now worldrenown artist for the project's relocation. In any case, you can't remember the last time you've seen such a real-life illustration of how discard and decay can somehow end up colorful and poignant and ultimately upbeat.

\section{www.hfmgv.org}

On the other side of town, but just a click away, you find another (perhaps more traditional) showcase of ideas: the Henry Ford Museum and Greenfield Village. This unique and huge indoor/outdoor complex illustrates innovations and ingenuity, and is one of the major tourist attractions in southeast Michigan. The kind of a place you can learn, study, inquire, or just take a peaceful walk back through the American centuries. Like seeing the Empire State Building when you're in New York City, or the Grand Canyon when you're in Arizona, you know you have to see it when you're in Detroit, if just so you can check it off your must-see list. Ed. note: Conference-goers will have the museum to themselves on Saturday night for an ACRL party.

\section{www.fordhouse.com www.umd.umich.edu/fairlane}

Speaking of Henry Ford, you're starting to get the impression that the guy had an impact on this town: there's the museum, the hospital, the college, the high schools and, oh yeah, the auto company. You can't help thinking that his and his son's estates would be worth walking around, to witness firsthand the physical manifestation of the wealth of one family, and, by extension, the rewards 
of the work of an entire city, as it is handed down from one generation to the next. The estates are quite different from each other and at opposite ends of the city, but they're both beautifully preserved architectural landmarks to icons of industry.

\section{bhere.com/ruins}

In stark contrast, you stumble across this site, dedicated to "The Fabulous Ruins of Detroit," equating some abandoned industrial and commercial and residential buildings in Detroit to the ancient ruins of Rome and Athens. You're not sure what to make of that juxtaposition, but the photographs and descriptions of the old, once-proud buildings are indeed haunting, and you're starting to get the idea that Detroit's cityscape is an interesting mix of the really new and the pretty old. You're not sure if you'd be embarrassed by the lack of preservation efforts, or proud of the moxy it takes to cut your losses and start anew.

In any case, Detroit seems like a big place that's enjoyed a lot of room to spread out and keep growing, and sometimes, obviously, it doesn't look back.

\section{www.foxsearchlight.com/polish/}

But lots of people do look back, and capture the spirit of Detroit on paper and on film. Elmore Leonard is a Detroit native, and keeps churning out those novels punctuated by somehow witty but dumb-guy dialogue, which you wonder how the novelist can capture seeing as how he lives in the tonier part of town.

Meanwhile, it might be your imagination, but it seems like Hollywood has caught on lately: "Out of Sight" (based on an Elmore Leonard novel), "Grosse Pointe Blank," "Hoffa," and "True Romance" are just a few of the flicks set and filmed in Detroit. Indeed, you're sorry you missed "The Polish Wedding" when it came out in theaters last summer, as you're a big Clare Danes fan to begin with, and you've learned that it was filmed in the Detroit enclave of Hamtramck.

Didn't some trendy magazine recently vote Ham-town as one of the "most trendy" cities in the United States? You're not sure what that even means if it's true, but you get a kick out of the idea of the leather-clad trendoids on their way home after a long night at the hip after-hours clubs and looking for latte passing the old ladies with babushkas on their morning kielbasa run. You're also getting a hankering for one of Hamtramck's famous paczki (pronounced "poonch-key", and looking not unlike a big fat jelly donut), found everywhere on Fat Tuesday (the day before Ash Wednesday). All this http'ing is starting to make you hungry.

\section{metrotimes.com}

Restaurants, you're interested in restaurants. Every city it seems has its weekly arts and entertainment rag, but Detroit's Metro Times is pretty sophisticated, with full-feature articles and investigative reporting that verge on real journalism, and you like its Web version for the online calendar of eventsthere's lots going on in the bars, in the concert halls, in the sports arenas, and, yup, in the restaurants. The dining reviews here are up-to-date and loaded with attitude, and you can even sort by price or cuisine or location. You're glad you like to experiment while dining out, because Detroit's evidently got a bit of everything-from Ethiopian to Greek to Middle Eastern to Irish to big, old midwest steakhouses.

Plus, the desserts tend to go beyond the merely huge and venture into the enormous -which is a good thing, because you like dessert. In general, though, whether you're interested in a swank establishment with an extensive wine list, or a lunch counter slinging cheeseburgers, you can rely on the Metro Times to give you a pretty good idea of what to expect, and for that alone you'd give it a rating of four forks.

All right, you've seen enough; you'll save the other tempting Web sites-like those for the Museum of African American History, Detroit Science Center, Detroit Public Library, Holocaust Memorial Center, Center for Creative Studies, Cranbrook Institute, etc.-for some realtime sightseeing once you get to the Motor City.

Sure, Detroit's not Disneyland, but it's clearly cosmopolitan and comfortable, and just different enough to keep things interesting: it's got that big-city pace, loaded with the usual as well as some unusual things to do and places to see, and filled with friendly folks who are rightfully proud to show off their town. You can't wait. 


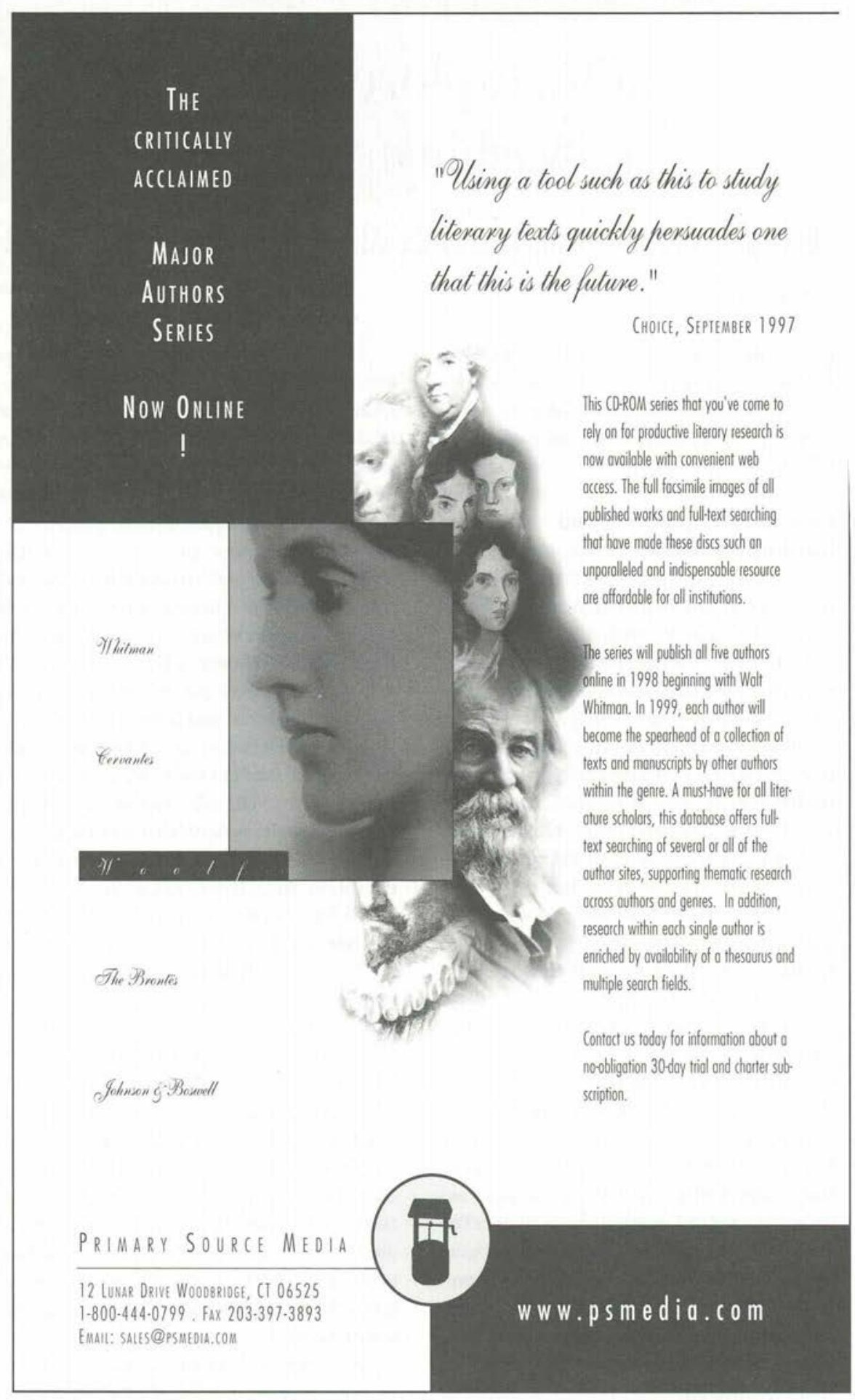

